Article

\title{
Shifting Religious Identities and Sharia in Othello
}

\author{
Debra Johanyak \\ English Department, The University of Akron, Akron, OH 44325, USA; dljohan@uakron.edu
}

Received: 2 July 2019; Accepted: 23 September 2019; Published: 20 October 2019

Abstract: Despite twenty-first century research advances regarding the role of Islam in Shakespeare's plays, questions remain concerning the extent of William Shakespeare's knowledge of Muslim culture and his use of that knowledge in writing Othello. I suggest that the playwright had access to numerous sources that informed his depiction of Othello as a man divided between Christian faith and Islamic duty, a division which resulted in the Moor's destruction. Sharia, a code of moral and legal conduct for Muslims based on the Qur'an's teachings, appears to be a guiding force in Othello's ultimate quest for honor. The advance of the Ottoman Empire into Europe with the threat of conquest and forced conversion to Islam was a source of fascination and fear to Elizabethan audiences. Yet, as knowledge increased, so did tolerance to a certain degree. But the defining line between Christian and Muslim remained a firm one that could not be breached without risking the loss of personal identity and spiritual sanctity. Denizens of the Middle East and followers of the Islamic faith, as well as travel encounters between eastern and western cultures, influenced Shakespeare's treatment of this theme. His play Othello is possibly the only drama of this time period to feature a Moor protagonist who wavers between Christian and Muslim beliefs. To better understand the impetus for Othello's murder of his wife, the influence of Islamic culture is considered, and in particular, the system of Sharia that governs social, political, and religious conventions of Muslim life, as well as Othello's conflicting loyalties between Islam as the religion of his youth, and Christianity, the faith to which he had been converted. From Act I celebrating his marriage through Act V recording his death, Othello is overshadowed by fears of who he really is-uncertainty bred of his conversion to Christian faith and his potential to revert to Islamic duty. Without indicating Sharia directly, Shakespeare hints at its subtle influence as Othello struggles between two faiths and two theologies. In killing Desdemona and orchestrating Michael Cassio's death in response to their alleged adultery, Othello obeys the Old Testament injunction for personal sanctification. But in reverting to Muslim beliefs, he attempts to follow potential Sharia influence to reclaim personal and societal honor.

Keywords: Shakespeare; Othello; revenge; religion; Islam; Muslim; honor; Sharia

Twenty-first century Western fears about Islamic extremism are not new. William Shakespeare makes reference to the threat of Turkish invasion and spread of Islam in nearly half of his dramas of the late sixteenth and early seventeenth centuries. The use of terms like "infidels" (King Richard III), "Mahomet" (King Henry VI-Part One), and "Turks" (in Hamlet, Othello, etc.) reminded Elizabethan audiences of the Ottoman advance into Europe with the intent of conquest and conversion. In Shakespeare's tragedy Othello, the hero, a Christian converted from Islam, murders his wife after being tricked into believing she has committed adultery. Subsequently learning of her innocence, he then kills himself to pay for his criminal act. Critics of the play have devised a number of theories about Othello's character and behavior. However, I believe Shakespeare reveals the dilemma of a Moorish husband divided between his dueling Muslim and Christian identities.

In several plays, Shakespeare features a non-Caucasian character who, despite villainous conduct resulting in disgrace or punishment, manages to draw our sympathy along with our condemnation. Aaron the Moor, Shylock the Jew, Caliban, and Othello offend viewers' moral and legal sensibilities. Yet, Shakespeare draws our attention to these characters' humanity, emphasizing some qualities that make 
them eerily similar to us. Their divided nature mirrors contradictions in ours. We see this in Othello's agonizing attempts to ignore Iago's accusations of Desdemona as well as his final repentance for her murder. This article will focus on Shakespeare's development of Othello's hybrid Muslim-Christian identity that ultimately leads to his downfall. Considering throughout various ways in which recent critical discussions of Islam in Othello in the past decade and a half have enriched our understanding of Shakespeare's tragedy, this article will seek to participate in these discussions even as it offers its own contribution to how Islam is treated in Othello. The information used in this article is not intended to convey an authoritative purview of Islam or its scriptures and interpretations. Rather, it offers introductory contexts from a lay perspective as consideration for potential influences on William Shakespeare's construction of his character Othello, recognizing throughout that Shakespeare neither directly mentions Sharia in the play nor demonstrates awareness of the various complex manifestations of Sharia within Islamic culture.

Sixteenth- and seventeenth-century travel reports, business exchanges, and harem tales, along with numerous encounters between eastern and western cultures, seemingly influenced Shakespeare's treatment of this theme of dueling identities. A growing body of contemporary research reveals new insights into Elizabethan understanding of Islamic culture and its impact on stage drama. But was Shakespeare familiar with the concept of the Qur'an-based Sharia, a code of conduct and honor principles governing family relations and social contexts? If so, how did his understanding impact the development of Othello's character? Othello the Moor is a naval general who, seemingly converted to Christianity as a youth (possibly by force), alternates between Christian and Muslim identities when confronted by allegations of adultery against his bride, Desdemona. Othello's wounded ego and his appeal to justice in murdering Desdemona becomes evident in his wavering between Christian identity as a husband emotionally struggling with the belief that his wife has been unfaithful and Muslim beliefs demanding justice to reestablish honor.

Othello's shifting identity can be considered within the larger framework of personal identity in the theater during Shakespeare's time. Although racial stereotypes played a role in Elizabethan perceptions of non-European beliefs and values, Peter Berek raises the question of the fluidity of social and religious identity on the Elizabethan stage: "The theater of the 1590s was obsessed by the possibilities that identity might be willed or chosen and social position achieved by deeds, not birth" (Berek 1998, p. 130). Plays like Tamburlaine, Richard III, and Shakespeare's tetralogy beginning with Richard II and ending with Henry $V$ underscore this theme. Marranos, or Iberian Jews converted to Christianity, are plausible representations of the notion that identity is not stable and can be created by individuals themselves, an idea that has stood the test of time. Othello is a prime example of shifting identities: He was presumably born Muslim, kidnapped into slavery, and converted to Christianity; he eventually became a Venetian general who secretly married into Venice's ruling class and led a military expedition to Cyprus. During the play, questions subtly arise as to whether he is Christian or Muslim, Venetian or Moor, honorable or criminal. This duality serves as the locus of his (dis)orientation and resulting actions.

Conversion, forced or not, represents the holistic transition from one religious or national identity to another, and in the English theater this transition often manifested in romantic and erotic matters. Jane Hwang Degenhardt notes in Islamic Conversion and Christian Resistance on the Early Modern Stage that religious conversion was presented on the stage in sexual as well as physical terms (Degenhardt 2010). In Othello, The secret marriage of Othello and Desdemona forms the crux of the conflict representing the threatened union of East and West with the advance of the Ottoman Empire into Europe. As a convert from Islam to Christianity, Othello's divided nature confronts first his wife and then himself as he struggles with his religious identity in response to his wife's alleged infidelity.

Marital conflict lies at the core of Othello's plot and invites scrutiny of Othello and Desdemona's sexual relationship as well as their religious beliefs. Because the marriage is never clearly consummated, the attempted union between East and West literally embodied in the union of Othello and Desdemona is doomed to failure, representing historical reality as well as Othello's insecurities. 
Indeed, Othello's identity is questioned from the beginning of the play. Daniel Boyarin argues that "the open secret at the heart of [Othello] is the secret of Islam in Europe ... the Moors had been ruling much of 'Christian' Europe for centuries" (Boyarin 2011, pp. 254, 256). In the play, Othello's marriage to Desdemona is challenged by Brabantio and the Venetian Senate, his naval command is criticized by Iago who envies Cassio's promotion, and soon Othello's military leadership in Cyprus will be rescinded. The person that Othello seems to be in Venice transitions during his brief tenure in Cyprus to become someone that colleagues and friends scarcely recognize. Thus, his identity shift is witnessed by many who are unable to explain it.

Despite the challenges to his legitimacy that Othello receives from the play's earliest scenes, Othello affirms his Christian identity in leading a naval force against the Ottomans and in using the plural pronoun "we" to designate Christians in danger of "turning Turk." Jonathan Bate describes Othello's Christian identity from the play's beginning:

To the play's original audience, one of the most striking things about the figure of Othello would have been that he is a committed Christian. The "ground" of the play is laid out in the first scene, when Iago trumpets his own military virtues: "And I-of whom his eyes have seen the proof/At Rhodes, at Cyprus, and on other grounds/Christened and heathen" [1.1.28-30]. These lines give an immediate sense of confrontation between Christian and heathen dominions, with Rhodes and Cyprus as pressure points. Startlingly, though, the Moor is fighting for the Christians, not the heathen. Again, consider Othello's response to the drunken brawl in Cyprus: "Are we turned Turks, and to ourselves do that/Which heaven hath forbid the Ottomites?/For Christian shame, put by this barbarous brawl" [2.3.170-71]. Such Christian language in the mouth of a Moor, a Muslim, is inherently a paradox. It suggests that Othello would have been assumed to be a convert. The "baptism" that lago says he will cause Othello to renounce [2.3.343] would have taken place not at birth but at conversion. The action of the play reconverts Othello from Christianity, through the machinations of Iago. (Bate 2001)

Iago's destructive rhetoric elicits Othello's bodily and emotional afflictions to damage Othello's fragile Christian identity and to promote a victim mentality. As Othello's physical health is impacted by epileptic seizures, his mental health is assaulted by Iago's torment about Desdemona's alleged adultery. Ignoring both Muslim and Christian injunctions to seek spiritual counsel in matters requiring sober judgment, Othello instead follows his own faulty reason until he is overtaken by passion.

\section{Islam and Sharia}

Although Muslim-Christian conversions abound in Elizabethan drama, Shakespeare's Othello produced in 1604 may be the only period drama to feature a Moor who shifts back and forth between Christian and Muslim identities. To try and understand Othello's murder of his wife, we should consider the influence of his Christian beliefs and latent Islamic principles, and in particular, the system of Sharia that governs social, political, and religious conventions of Muslim life. The following is a description of the "History of Sharia":

Shariah is an Arabic term used to designate Islamic law ... The shariah is not deemed a religious law by virtue of the subject matters it covers, for these range far beyond the sphere of religious concerns strictly speaking and extend to the mundane affairs of everyday life ... Although Muslims agree that they are bound by the shariah, the interpretations of its requirements have differed historically according to sectarian and school divisions, ... In the Islamic view, governments exist only to ensure that the shariah is properly administered and enforced ...

Should the government of a Muslim society fail in its obligation to uphold the shariah as the positive law, or the judges of this world fail in their obligation to administer justice in 
accordance with the shariah, the individual believer would still be held to the responsibility incumbent upon all Muslims to conform their behavior to the shariah. (Jones 2004)

Thus, practicing Muslims are personally responsible for following Sharia when judges and societies fail to uphold Qur'anic laws. A Muslim living in Western society would be expected to adhere to Sharia practices despite the lack of a Sharia court, a matter that will become germane to Othello later in the play when he prepares to kill Desdemona, an execution he pronounces as just despite the lack of any legal or spiritual directive.

\section{Adultery and the Death Penalty}

Othello's murder of Desdemona (based on Iago's false accusation of adultery) is the chilling climax of the play. The killing appears to be premeditated rather than a crime of momentary passion. Does Othello kill Desdemona for personal revenge? Or, as military commander of the Cyprus garrison, does Othello murder his wife as deserved punishment for her alleged immorality? His frequent use of the word "honor" seems to invoke an intentional judicial act to deal with her criminal and immoral behavior and to restore justice to the local / military community.

In Renaissance Europe, adultery was often treated a serious crime. In many regions, a husband could be excused for killing an adulterous wife, and in some cases, her murder would not be judged a crime. Generally, European royal wives convicted of adultery were judged to have committed treason against the state, which could result in execution ("Women"). Other cultures practice honor killings as well. For example, the Japanese form of honor suicide, seppuku, was originally practiced by samurai to preserve or restore honor, and later the act spread to non-Samurai people. Honor killings are carried out as a means perceived by the perpetrator, often a patriarchal or matriarchal authority, of restoring honor to a family or an individual who has been damaged by the immoral or sexual actions of another person.

The "honor killing" principle witnessed in many global regions remains active and controversial today, although the practice is not restricted to Sharia adherents. The earliest Abrahamic faith (Judaism), from which Christianity and Islam derive, prescribed the death penalty for adultery in priestly law as found in the Book of Leviticus: "And the man that committeth adultery with another man's wife, even he that committeth adultery with his neighbour's wife, the adulterer and the adulteress shall surely be put to death" (Leviticus 20:10 KJV). The death penalty was God-ordained for personal spiritual sanctification: "Sanctify yourselves therefore, and be ye holy: for I am the LorD your God. And ye shall keep my statutes, and do them: I am the Lord which sanctify you" (Leviticus 20:7-8 KJV). Othello might have had this Scripture in mind from his Christian indoctrination. As the military leader of Cyprus, it makes sense that the legal jurisprudence he had learned doctrinally would be the guiding response to Desdemona's crime. Othello in Cyprus lacks either a contemporary Christian spiritual authority or a Sharia court venue through which to process Desdemona's perceived adultery. Lacking these means, as the military ruler of Cyprus, he assumes the role of judge, jury, and executioner. Othello realizes from Brabantio's warning that Desdemona had deceived her father in eloping (1.3.292-93), and Iago later reminds Othello of this subterfuge (3.3.206). The fear is planted from the start that Desdemona is capable of committing further immoral acts (since familial disobedience could be punished judicially) that would subsequently justify (or require) his revenge. Othello comes to believe this has happened, and Desdemona must be punished and prevented from committing further crimes, since early modern Europe assessed adultery committed without the spouse's knowledge as an illicit act (vs. cuckoldry if the husband was aware but failed to punish or interfere with the adultery). Marital infidelity was often treated on the stage as an act that led to tragic outcomes: "Adultery was thought to lead to socially tragic ends, such as the death which occurs at the end of 'Tis Pity She's a Whore, when Giovanni kills his sister Annabella" (Almadani 2014, p. 61).

It is well documented that Shakespeare was thoroughly familiar with the Bible and often referenced it in his writing (see, for example, Marx 2000; Shaheen 1999; and Hamlin 2013). Shakespeare would have known Levitical law. Although any knowledge that Shakespeare may have had of Sharia is necessarily speculative, and though we cannot know precisely what Shakespeare might have intended 
Othello to believe or practice about Christianity or Sharia, it may be inferred from his eventual repeated use of the word "honor" that Othello's intent became to follow what he understood to be the Sharia code based on his Muslim origins, which seems to be a regional rather than universal interpretation of Sharia laws pertaining to adultery.

\section{Islam in Early Modern English Literature and Other Sources}

In "Shakespeare and Religion," John Cox asserts that Shakespeare's knowledge of non-Christian religions was based largely on reading (Cox 2018, p. 1). Cox refers to Cyndia Susan Clegg's point that several books on Moors and Turks were readily available in English at the time Othello was written, noting the strong emphasis on 'rigorous notions of justice and law in Islamic societies'" (Clegg 2006, p. 3). Indeed, even before Shakespeare's lifetime, the British were beginning to gain access to new information about Islamic culture. Andrew Borde's The First Book of the Introduction of Knowledge (1547) "describes the customs and manners of various nations, from the English and their neighbors to the Moors, the Turks, the Egyptians, and the Jews." He indicates that the Moors who were brought into Christendom kept "much of Mohammed's law, as the Turks do" (Borde 1547). This suggests that Muslims who became Christianized through slavery or release often continued to practice Islam, which would have been noteworthy in a Christian England that was still struggling with religious Catholic-Protestant conflict. In the late sixteenth century as playhouse drama drew inspiration from history, travel accounts, and literature, there were "numerous sources available" about Islamic religion and culture (Vitkus 2000, p. 18). In the theatre, popular dramas include Christopher Marlowe's Tamburlaine plays (1587-8), along with Robert Greene's Selimus (1588) and Orlando Furioso (1589), depicting Islam and Turkish court life (Vitkus 2000, p. 126). Shakespeare had ready access to these sources.

While Cinthio's Hecutommithi is the widely-acknowledged primary source for Shakespeare's Othello, contemporary accounts of Turkish life by English travelers offered additional insight to Islamic society. Turkey at the heart of the Ottoman Empire appears to be the best-known source for Islamic culture and Sharia values. A well-known story by Richard Knolles in his General Historie of the Turkes reveals the emphasis placed on honor over love. Mahomet the Great, a Turkish sultan, fell in love with a beautiful Grecian captive and spent his time with her as courtiers began to worry about his neglected duties. Mustapha Bassa, a long-time courtier, courageously voiced concern to the Sultan about the need to protect the ruler's honor and national security. At first incensed, Mahomet then arranged a banquet to which he brought the woman, gorgeously dressed. Leading her before the guests that had begun to question his ability to rule, the Sultan grabbed the concubine by her hair, pulled his falchion, and cut off her head (Knolles 1603, p. 351). Her death illustrates the preeminence of honor as a critical principle of the Turkish court. The concubine's name was Irene, or "Hiren" in the Westernized version, and Shakespeare's contemporaries, including George Peele, made reference to the account. Shakespeare himself includes a line in his play 2 Henry IV, "have we not Hiren here?" (2.4.159-60). The plot of Othello represents a mini-version of the tale, where masculine honor-especially in a leader-when threatened by love or sex, must be preserved even at the cost of human life.

European captives who converted to Islam often held positions of authority in the Ottoman Empire, and some maintained contact with their homelands. Although ostracized by their European countries of origin as "renegades," many enjoyed positions of authority in Europe, "providing money, support, and protection to their relatives abroad and sometimes even engaged in charitable works in their former homes. In doing so, Christian-European renegades behaved no differently from fellow members of the Ottoman elite ... who funded public works in their birthplaces and provided patronage, obtaining lucrative offices in the sultan's service for their Muslim relatives and appointments in the Orthodox Church for their Christian kin." European diplomats within the Ottoman empire served as translators, guides, and sometimes as spies (Graf 2018).

Moreover, some converts that escaped Muslim countries brought valuable information back to England. Since the Turkish conquest of Constantinople in 1453, the advances of the Ottoman 
Empire in the Mediterranean and into Europe, and piracy attacks on English and European sea vessels, Elizabethans generally viewed Muslims as aggressive and bloodthirsty. "It is estimated that the Barbary pirates captured and enslaved anything between 800,000 and 1.25 million Europeans ... Under sharia law the position of Christians [in Muslim-conquered territories] was never secure" (Scott 2016). North African pirates raiding England's western coasts took slaves, with many converting to Islam willingly for an opulent lifestyle through serving the royal household. Daniel Vitkus points out that these converts became members of the "Muslim religious community" (Vitkus 2000, p. 4), where they would have been indoctrinated into Sharia practices. Some expatriates eventually returned to England with tales of converts and renegades that could be adapted as stage plays. The growth of international trade further increased public knowledge about the East. Brotton (2016) points out that by the late 1580s "hundreds, perhaps thousands of Elizabethan merchants, diplomats, sailors, artisans and privateers were plying their trade throughout the Islamic world, from Marrakesh to Qazvin in Persia" (Brotton 2016, p. 133). He also notes, "The registers of the Company of Stationers of London reveal that an estimated sixty books were published in Elizabeth's reign on subjects relating to the Ottomans, over half of them in the 1590s" (Brotton 2005, pp. 204-5).Thus, the Islamic way of life became increasingly accessible to the public.

The most significant source of Islamic knowledge is Leo Africanus's A Geographical Historie of Africa (Brians 1526), a valuable resource to Europeans on African geography and culture. Some scholars believe that Shakespeare modeled Othello on Leo Africanus, who experienced an adventurous lifestyle:

Still a young man, he was captured by Christian pirates and presented as an exceptionally learned slave to the great Renaissance pope, Leo X. Leo freed him, baptised him under the name "Johannis Leo de Medici," and commissioned him to write in Italian the detailed survey of Africa which provided most of what Europeans knew about the continent for the next several centuries ... Leo is said to have died in 1554 in Tunis, having reconverted to Islam (Brians).

Writing extensively about African and Muslim culture, Africanus mentions facts that Shakespeare seems to have used in his play: the importance of female veiling, the custom of wives riding into battle with husbands, and violent punishments meted out to adulterers. There were tales of renegados, or Westerners who "turned Turk" for various reasons: "Now the Christians become Turkes, partly upon some extreme \& violent passion. Cherseogli ... turned Turke to bee revenged of his father, who took from him his wife, amidst the solemnitie of the marriage" (Leo 1600). In the last example, Cherseogli adopts a Muslim identity to avenge the loss of his wife. A similar theme appears in Othello.

\section{Muslims in Shakespeare's London}

In addition to the above sources, Elizabethans had first-hand observations into Muslim life in the late 1500s and early 1600s, which the following paragraphs will outline. Practicing Muslims lived in London at this time, which must have fed gossip and cultural exchanges. According to William Dalrymple in a Foreword to Gerald MacLean's Re-Orienting the Renaissance: Cultural Exchanges with the East (MacLean 2005),

Elizabethan London had a burgeoning Muslim community which encompassed a large party of Turkish ex-prisoners, some Moorish craftsmen, a number of wealthy Turkish merchants and a "Moorish solicitor". (MacLean 2005, p. xix)

Intercultural, commercial, intellectual, and social connections with these individuals would have broadened Londoners' perceptions of Islam.

A recent BBC article titled "Britain's first black community in Elizabethan London" offers an historic perspective on blacks who were or had been Muslim Moors and thus identified by religious beliefs rather than race, indicating that "Black" was more or less synonymous with "Moor," which in 
turn represented Muslim identity. ${ }^{1}$ Shakespeare must have known about their growing population and the government's efforts to expel blacks, many from Moorish roots in northern Africa, from England toward the end of Elizabeth's reign. Wood reveals that the increasing numbers of black people in London around 1600, many freed from Spanish ships, created a population burden, and in 1602, Cecil was pressuring merchants to return some freed slaves to Barbary (Wood 2012).

Imtiaz Habib claims that between 1550 and 1660, English archives contain 277 citations of blacks (many or most of Moorish origins) in London and the countryside. Several records circa 1590s name "Resonabell a Blackmore", resident since 1579, a short distance from Philip Henslowe's Rose theatre. One of his sons, "Edward the sonne of Reasonabell Blackman silk weaver" offers a tantalizing vision of Shakespeare's observing the silk weaving process and incorporating an image of a silk handkerchief in Othello that was woven by an Egyptian and given by Othello's father to his mother. Public records show that blacks lived and worked in proximity to the theatre district, for example, in Shoreditch, and in Bishopsgate, one of Shakespeare's addresses. Habib argues that such a close association "makes unavoidable their [playwrights' and actors'] intimate social knowledge of black (Moor) people" (Habib 2014, pp. 131,136). In all probability this included variations of Sharia practice.

Public records after 1606 indicate certain black individuals were Christian, baptized, or of a Christian household, which implies that those without the designation before this time were not Christians, as religious affiliation is not mentioned except for baptism into Christianity. The omissions suggest adherence to Islam (or another faith). An established and integrated Muslim population would have been noticed.

In late summer and fall of 1600, the visit of Abd-el-Oahed ben Massaood, Moroccan ambassador to London, may have influenced Shakespeare's writing of Othello a few months later. The dignitary and an accompanying delegation arrived in quest of an Anglo-Moroccan political alliance. Interestingly, he "observed the Islamic Hadith injunction against figurative representation, never showing his face and speaking in public from behind a veil" (Brotton 2016, p. 267). Jonathan Bate points out that Shakespeare's theatre company "played at Court that Christmas, so he may have seen the Barbarian delegation in the flesh" (Bate). Witnessing Sharia practices first-hand may indeed have stirred Shakespeare's imagination.

\section{Othello and Religion}

Shakespeare's knowledge of Muslim beliefs and practices are manifest in his tragic depictions in Othello: a wronged father, a rebellious daughter, an exotic suitor, and a deceptive conniver. However, the play goes further than portraying a non-Caucasian outsider's downfall. Othello's history, as told to Brabantio and Desdemona, suggests that he was born in a Muslim society, evidenced in his youthful capture and enslavement, and subsequent conversion to Christianity. Shakespeare portrays Othello as a capable naval commander whom the Venetians trust to defend their state. Yet, he also reminds us that Othello is a non-Venetian outsider with a murky past. Senator Brabantio-Othello's new father-in-law-does not accept Othello as an equal, evidenced in his horror at daughter Desdemona eloping with the Moor. Roderigo describes Othello to Brabantio as a "lascivious Moor" (1.1.126) and "an extravagant and wheeling stranger / Of here and everywhere" (1.1.136-37), stoking the father's revulsion over Othello's Moorish background and unsettled history.

Brabantio laments, "It is too true an evil" (1.1.160) and calls his daughter's marriage "treason of the blood" (1.1.169), immediately suspecting the supernatural influence of "charms" (1.1.171). Blending moral and criminal complaints, he condemns the marriage and believes his daughter has been victimized by magic. When Iago warns Othello of Brabantio's ire, Othello relies on military "services ... done the signiory" (1.2.18) and trusts his "parts," "title," and "perfect soul" (1.2.31) to

1 To Shakespeare and his contemporaries, Turk, Arab and Moor all represented the Islamic "other," but they were not necessarily homogenized into a single image of generic "barbarianism" (Bate 2001). 
support his character against public condemnation. Othello's rational response to emotional criticism underscores his seemingly stable nature and personal confidence at this point.

Despite Othello's celebrated reputation as a successful military general, Brabantio insults Othello as a thief and berates him as an enchanter, characterizing his son-in-law as a criminal and necromancer (1.3.60-64). Thus, Brabantio's recent regard for Othello is instantly transformed into loathing because of the marriage. Othello reveals to the Duke: "Her father loved me, oft invited me; / Still questioned me the story of my life / From year to year-the battles, sieges, fortunes / That I have passed" (1.3.128-31). Yet, the two men's bond is shattered by the elopement, and Brabantio insists before the Duke and Senate that Othello must have practiced forbidden arts to win Desdemona's affections: "Why this should be? I therefore vouch again / That with some mixtures pow'rful o'er the blood,/Or with some dram, conjured to this effect, / He wrought upon her" (1.3.103-6). Unapproved marriage is one of the reasons given for honor killing in societies that endorse Sharia codes of conduct. Brabantio's rejection of Othello as an acceptable husband to Desdemona serves to undercut Othello's full legitimacy as a member of Christian society, and when he declares to the exiting Brabantio and the remaining Iago, "My life upon her faith!," he explicitly places his very self at the mercy of Desdemona's sexual integrity and the truthfulness of his ensign, who in the same line he terms "Honest Iago" (1.3.294). The fragility of Othello's being, which he unwittingly admits, renders him vulnerable to the tragic effects of his uncertain religious identity. ${ }^{2}$

Othello's misplaced trust in "Honest Iago" leaves Othello vulnerable to his ensign's insidious deception. Believing that he has been unfairly overlooked in favor of Michael Cassio for a military promotion, Iago devises a vengeful plan to trick Othello into believing that Desdemona is having an affair with Cassio. Iago's plan strikes at Othello's vulnerability as a racial minority with a dual religious identity. The ideal of honor trumping love grows in Othello's mind as his Muslim identity is awakened by Iago's prodding to take action against his errant wife.

For her part, Desdemona does not consistently practice conservative female propriety, a failure which in some Muslim societies has long been perceived as a sign of sexual laxity. Alharbi (2015) notes that although "the system of guardianship law differs from one Islamic state to another depending on social practices, customs, and the culture of each state ... Today certain legal provisions persist [from past practice] that require women to have the presence and / or approval of a male guardian in order to benefit from such basic rights as work and freedom to travel" (Alharbi). Strikingly, when Roderigo informs Brabantio of the secret marriage, he describes Desdemona as being "Transported, with no worse nor better guard/But with a knave of common hire, a gondolier, / To the gross Clasps of a lascivious Moor" (1.1.124-26). For Desdemona to move about in public unescorted by a family member or trusted servant but rather with a "knave of common hire" — an unknown stranger-was to jeopardize her reputation even in Christian Venice, but Roderigo's words carry special significance when considered within the context of Othello's Muslim upbringing. Furthermore, in Cyprus, Desdemona leaves the sanctity of the citadel home without her protective husband or servant to meet with Cassio. Sharia suggests such behavior compromises a female's virtue, which then spreads contagiously to her family, goading male relatives like a father, brother, uncle, or husband to take action, i.e., discipline and restoration if possible, or an honor killing if the woman cannot be rehabilitated. Since Desdemona has already betrayed her father and demonstrated impropriety by eloping with Othello, her virtue has been smudged. However, Othello—newly married and rooted in Christian duty to fight the Turks—sees no need to worry. Redemption by marriage with the male transgressor is allowed in Sharia when a woman has been raped or found guilty of a sexual relationship outside of marriage, or if she has

2 However, Shakespeare is careful not to attack Islam while hinting at its presence. Matthew Dimmock suggests that Shakespeare avoids direct confrontation with Semitic faiths: "Shakespeare's various allusions to the two Abrahamic non-Christian religions indicate an awareness of their dominant forms ... but also an unwillingness to blindly reproduce those forms ... the Mahometan [is] denied either scriptural congruence or religious coherence" (Dimmock 2015, p. 298). Shakespeare reveals impressions of Islam and Sharia to his audiences without condemning these religious practices. 
chosen an unapproved spouse. Since Venice and Cyprus were Christian states, and Othello at least a nominal Christian, there is no need for redemptive action.

The more serious threat momentarily is Iago's plot against Othello because the desired naval promotion was given to Michael Cassio. As part of his revenge plan, Iago incites an alcohol-fueled brawl among the soldiers, requiring Othello to chide them for unbridled aggression and violence:

"Are we turn'd Turks, and to ourselves do that / Which heaven hath forbid the Ottomites? /

For Christian shame, put by this barbarous brawl". (2.3.170-72)

His statement ironically foreshadows that soon Othello will turn Turk in allowing himself to accept Iago's false reports of Desdemona and Cassio, and in exacting judgment against his wife and himself without consulting a Christian priest or a Sharia court. After hearing Montano's report of the brawl, Othello's reason is shaken: "Now by heaven, / My blood begins my safer guides to rule, / And passion, having my best judgment collied, / Assays to lead the way" (2.3.204-7).

Seeing Othello becoming malleable, Iago states in a soliloquy that Desdemona's influence over her husband is capable of remolding his Christian faith:

And then for her

To win the Moor, were ['t $t$ to renounce his baptism,

All seals and symbols of redeemed sin,

His soul is so enfetter'd to her love,

That she may make, unmake, and do what she list,

Even as her appetite shall play the god with his weak function. (2.3.342-48)

This renunciation effectively occurs when Desdemona's actions unwittingly incite Othello to "turn Turk" and deal with her alleged adulterous behavior.

After Othello demotes Cassio for drunken brawling, Iago manipulatively directs Cassio to plead with Desdemona to request that her husband reinstate the disgraced former lieutenant. Following Iago's advice, Cassio requests "some brief discourse with Desdemona alone" (3.2.51-2), which again places Desdemona in private contact with a non-relative male. Desdemona promises to argue Cassio's case with Othello. Iago arranges for Othello to catch Desdemona with Cassio, and then raises suspicions:

Cassio, my lord? No, sure, I cannot think it,

That he would steal away so guilty-like,

Seeing your coming. (3.3.38-40)

Desdemona's subsequent greeting to Othello seemingly confirms Iago's claim with the inflected word "suitor" although she uses it, perhaps playfully, in a general sense of 'petitioner': "I have been talking with a suitor here" (3.3.42). Desdemona's naïve use of the word reveals another lapse in her judgment, one that will incense Othello, whose sensitivity to such impropriety is heightened by his Islamic background and is manipulated by Iago.

Unaware of Othello's suspicions planted by Iago, Desdemona mounts a series of pleas to have Cassio reinstated, going so far as to praise Cassio at Othello's expense and seeming to suggest Desdemona's larger discontent with Othello's person even as she expresses her commitment to Cassio:

What? Michael Cassio,

That came a-wooing with you, and so many a time,

When I have spoke of you dipraisingly,

Hath ta'en your part- - to have so much to do

To bring him in! [By'r lady], I could do much. (3.3.70-74) 
Desdemona presses her husband for nearly forty lines on behalf of Cassio until Othello meekly complies: "Prithee, no more. Let him come when he will; / I will deny thee nothing". (3.3.75-76)

Nonetheless, Othello's acquiescence draws another eight lines of complaint until the matter is settled to Desdemona's satisfaction. We may rightly suspect that Iago's previous knowledge of Desdemona's assertive and socially questionable foray to meet Othello inspired him to have Cassio set Desdemona's determination in motion on Cassio's behalf.

Also noteworthy are Othello's words when Desdemona leaves with Emilia. He groans:

Excellent wretch! Perdition catch my soul

But I do love thee! And when I love thee not,

Chaos is come again. (3.3.90-92)

Shakespeare hints here that if Othello's love for Desdemona dies, he will lose his Christian faith—with his use of the term "perdition," meaning "utter destruction" and "spiritual ruin and damnation," alluding to a non-Christian spiritual state. The coming of "chaos" suggests the confused nature of Othello's shifting identity as he becomes increasingly disoriented by Iago's prodding.

If jealousy were not enough to ruin Othello's peace of mind and confuse his religious identity, Iago pricks Othello's honor through the implied loss of reputation:

Good name in man and woman, dear my lord,

Is the immediate jewel of their souls.

Who steals my purse steals trash; 'tis something, nothing;

'Twas mine, 'tis his, and has been slave to thousands;

But he that filches from me my good name

Robs me of that which not enriches him

And makes me poor indeed. (3.3.155-161)

Confronted with the threat of a damaged reputation, Othello's Christian ideals are eroded by his emergent Muslim honor. Up to this point he has relied on his military reputation and service to Venice to sustain his good name. A subtle hint of Islam's pull emerges with his use of the word "moon," the symbol of Islam:

Think'st thou I'd make a life of jealousy,

To follow still the changes of the moon

With fresh suspicions? (3.3.177-79)

Though the moon here implies changeability and inconstancy, the symbol suggests that Othello may indeed follow the Islamic moon and revert to Muslim idealism. ${ }^{4}$

The handkerchief Othello gave Desdemona upon their marriage is also relevant to his shifting religious identity. The handkerchief, he claims, is imbued with a spell to ensure marital faithfulness. To lose it, he insinuates, means the handkerchief's erstwhile possessor's husband will "hold her loathed" and "hunt / After new fancies" (3.4.62-63). Even more significant in light of Othello's aforementioned

3 I refer to the Oxford English Dictionary Online, definitions 1a and 2a.

4 Dennis Britton rightly observes how Iago's manipulations of Othello's emotions regarding Desdemona serve as a catalyst to the chaos of Othello's shifting religious identities: "If romantic love can cement a religious identity, Iago shows that dissolving the relationship between Othello and Desdemona can undo Othello's Christian identity, transforming him into a 'turban'd Turk' at the end of the play" (Britton 2014, p. 34). 
statement regarding "perdition" is his statement that "To lose't [the handkerchief] or give't away were such perdition / As nothing else could match" (3.4.67-68). Indeed, Desdemona's loss of the handkerchief is a significant catalyst to bring about the "perdition" that Othello warned of. Ironically, Desdemona loses the handkerchief not because, as Iago incites Othello to believe, she has given it to Cassio, but because, when he develops a headache that may be a symptom of his epileptic condition, Othello rebuffs Desdemona's offer of the kerchief for his pain: "Your napkin is too little" (3.3.288). In pushing the handkerchief away, he causes it to fall.

As they leave, Emilia picks up the handkerchief and explains its significance:

This is her first remembrance from the Moor.

My wayward husband hath a hundred times

Wooed me to steal it, but she so loves the token

(For he conjured her she should ever keep it)

That she reserves it evermore about her ... (3.3.291-95).

Thus, Othello gives the handkerchief to Desdemona as a token of marital fidelity. She keeps it "about" her as a protective talisman. Possessing the kerchief by Emilia's theft, Iago steals Desdemona's protective charm, leaving her vulnerable and exposed even as he inspires Othello to pursue "perdition" while delving into the "chaos" of his shifting religious identity.

My article, "Turning Turk," Modern English Orientalism, and Othello," explores the handkerchief's veiling symbolism as representative of the marital "covering" provided Desdemona by Othello as demonstrative of Sharia values. The handkerchief is a multifaceted icon rich with meaning. In the Ottoman Turkish seraglio, the emperor would indicate his choice of paramour for the night by giving a wife or concubine his handkerchief (Johanyak 2009, p. 90). Handkerchiefs were among the lavish gifts sent to Queen Elizabeth from Safiye, the mother of Mehmed, heir to the Ottoman Sultanate, in their exchange of

gifts of richly worked costumes and pieces of fined died [sic] fabrics ... One account describes "an upper gowne of cloth of gold very rich, an under gowne of cloth of silver, and ... two handkerchers [sic] wrought with massy gould" ... Years later when Safiye's son Mehmed III ruled, and Safiye was Valide Sultan, Elizabeth received "a robe and a girdle and two handkerchiefs worked with gold and three worked with silk" according to the custom of this kingdom. (MacLean 2005, p. 16)

Handkerchiefs played a public role as much as a private one through their intricate design, their public display, and their intimate exchange. They were often worn visibly on the body as a token of belonging to a certain household or family. They also served as romantic favors to signify a private relationship. Desdemona's handkerchief carries a spell that, when lost, would allegedly reveal her infidelity and incite her husband to a state of emotional and spiritual chaos.

As Iago continues to build an anecdotal case against Desdemona and Cassio, Othello, believing he has lost possession of his wife, returns to the theme of honor, which remains under his control, and groans, "[Her] name, that was as fresh/As Dian's visage, is now begrimed and black/As mine own face" (3.3.387-88). Iago's false report of Cassio's dream and the missing handkerchief sends Othello into the abyss of hopelessness where his ostensibly Christian nature is overcome by a fiendish hatred that invites the very perdition Othello has twice warned of:

Arise, black vengeance, from the hollow hell!

Yield up, O love, thy crown and hearted throne

To tyrannous hate! Swell, bosom, with thy freight,

For 'tis of aspics' tongues!

(3.3.447-50) 
The vengeance Othello calls upon is portrayed by his own words a damnable thing, yet it may well be in line with his confused spiritual values and a (mis)understanding of Sharia.

Another manifestation of Othello's shifting religious identity occurs when Lodovico summons Othello to Venice, an announcement which grants Desdemona relief because Cassio is reinstated as her husband's replacement in Cyprus. However, Othello mistakes her relief for love of Cassio, and enraged, strikes her publicly (4.1.231-41). When Lodovico protests, Othello accuses Desdemona of immorality in slanderous terms: "Sir, she can turn, and turn; and yet go on / And turn again" (4.1.253-54).

His repeated use of "turn" refers to her accused sexual promiscuity. Lodovico, Iago, and "Attendants" are shocked by Othello's strange behavior, but we ought to remember that Sharia law dictates that the charge of adultery must be supported by four reliable witnesses. Here, Iago, Lodovico, and "attendants" (two or more) fulfill this criterion loosely, as adultery must be witnessed as it occurs; perhaps for Othello, Desdemona's declaration of "the love I bear to Cassio" (4.1.233) is sufficient testimony of her infidelity. Othello's violent response may represent Shakespeare's (or Othello's) imperfect understanding of Sharia. According to the Qur'an, adulterers, if convicted, may be whipped by 100 lashes. On the other hand, Sharia may be locally and individually applied according to the dictates of the presiding "judge" - in this case Othello, since there is no local Islamic court. Othello's single slap to Desdemona could symbolically represent the 100 lashes. The other Qur'anic response to adultery is to confine the erring wife at home. Othello orders Desdemona away twice, and she obediently returns to the citadel (4.1.258-60). These actions hint at Othello's beginning to transition to Muslim identity and application of Sharia law, for there is no attempt to logically discuss the problem with his wife or to woo her romantically away from the perceived rival, Cassio.

Lodovico remarks on the dramatic change in Othello's character, recognizing the "chaos" that has overwhelmed him and implicitly recognizing the identity shift he now displays:

Is this the noble Moor whom our full Senate

Call all in all sufficient? Is this the nature

Whom passion could not shake? whose solid virtue

The shot of accident nor dart of chance

Could neither graze nor pierce? (4.1.264-68)

Iago responds, "He is much changed" (4.2.268).

Lodovico continues: "Are his wits safe? Is he not light of brain?" (4.2.269)

Returning to the citadel to confront Desdemona, Othello demonstrates again the confusion of his struggling identity. Vacillating between love and loathing, Othello calls his wife a "public commoner" (4.2.73), seemingly alluding to incidents in which Desdemona was ushered to their elopement by the unknown gondolier, and later, unchaperoned, met with Cassio. Trivial as these actions may seem, compounded, they build on Iago's accusations to render Desdemona unchaste in Othello's imagination and loom all the more significant in light of Othello's implicit return to Muslim beliefs about honor. Following Othello's interrogation of Desdemona in the citadel, Emilia-like Lodovico-notes with surprise his fluctuating nature, declaring, "Here's a change indeed!" (4.2.106).

Upon his return to the citadel, Othello again demonstrates his alternating character. In his initial words to Desdemona, he articulates a kind of twisted Christian grace when he urges Desdemona to pray, offering her soul a chance of redemption before he kills her body (5.2.25-32). At the same time, Othello articulates Sharia-like concerns with honor and societal cleansing. Her death, he believes, will free his reputation from the stain of her immorality, and will free society from her immoral influence. He states: "Yet she must die, else she'll betray more men" (5.2.6). ${ }^{5}$

5 Dennis Britton observes how "If romantic love can cement a religious identity, Iago shows that dissolving the relationship between Othello and Desdemona can undo Othello's Christian identity, transforming him into a 'turban'd Turk' at the end of the play" (Britton 2014, p. 34). 
His accusations and threats reveal a cold and legalistic approach to enacting justice against his seemingly erring wife. He accuses Desdemona of giving Cassio her handkerchief, which she truthfully denies (5.2.48-50). Othello's response hints at his problematic application of Sharia to his judgment of his wife, whom he has already pronounced guilty:

O perjured woman! Thou dost stone my heart,

And mak'st me call what I intend to do

A murder, which I thought a sacrifice. (5.2.63-65)

Othello's accusation of Desdemona "stoning" his heart, although referring to his heart turning cold because of her denial of wrongdoing, also calls to mind traditional Sharia stoning of adulterers under conditions that are not precisely met in this case. However, as the lone "judge" of the crime, according to some hadith interpretations of Sharia, Othello may impose the punishment for adultery he feels is suitable based on his application of hadith traditions given by Islamic scholars, which vary widely (Fatoohi 2015) ${ }^{6}$ In killing Desdemona, Othello undertakes the Sharia mandate to restore honor to his name and justice to society. Wounded by the belief that his bride has sexually betrayed him, Othello turns to Sharia for authority to administer his notion of justice that the Christian legal system cannot provide. ${ }^{7}$

Othello also attempts to define his murder of Desdemona as a personal "sacrifice" rather than a crime of passion, denoting his actions as a religious duty rather than a civil felony, a notion more in keeping with Sharia than the Christian idea of relational justice. Smothering her, he claims to be "merciful" in not letting Desdemona linger (5.2.88), recalling the Qur'anic Bismillah: "In the name of God, the merciful and compassionate," a blessing frequently used by Muslims (Free Dictionary). ${ }^{8}$

6 Qur'anic Studies claims that the noun form of "hadith" occurs twenty-three times in the Qur'an, while the plural form ("ahadith") appears five times; there are also variations in eight other verses of the Qur'an. The term generally refers to a story, speech, or news, not necessarily religious:

Any hadith consists of two parts, the first is known as "isnad" or "sanad," and the second is known as "matn" ... in the terminology of hadith it refers to the chain of transmitters of the hadith ... and support the historicity of the hadith. The interpretation of Islamic law pertaining to a wide range of behaviors, including adultery, may be gleaned from numerous sources and scholars. (Fatoohi 2015)

7 Amid our discussion of Othello and Sharia, we do well to recognize that Islamic scholars are careful to explain that the Qur'an typically advocates mercy for adultery:

... one fails to find a single verse of Qur'ān ordering the penalty of death by stoning-as if by its absence, Allah were saying this is a punishment only for the most extreme cases of flagrant and wanton sexual activity in public, actions which will eventually destroy the moral fiber of the community. (Kabbani 2007)

At the same time, in some judgments of adultery, lashes are the penalty, as explained by Islamic commentators like Yusuff (1999):

The Qur'an mandates: "The adulteress and the adulterer, flog each of them (with) a hundred stripes, and let not pity for them detain you from obedience to Allah ... " (24:2)

Moreover, some argue that 100 lashes are tantamount to a death penalty. Others suggest that the Qur'an stipulates the death penalty for societal corruption. As discussed earlier, since Othello claims to kill his wife before she can defile more men, he could justify her death to protect society at large. It can also be argued that Othello's striking of Desdemona in public with Lodovico and at least three other witnesses serves as the symbolic "lashing" prescribed by Sharia, along with sending his wife home for confinement. (Significantly, however, Othello has no optical proof—as required by Qur'anic law—except for the circumstantial handkerchief.)

8 Cyndia Susan Clegg has recently explored the spiritual meanings of Othello's killing of Desdemona and resulting self-judgment based on two warring religious systems in Othello's character. She argues that Othello is "a tragic figure driven more by law than lust, and more by justice than passion" while she references early modern Islamic and Middle Eastern strong stands against adultery (Clegg 2019, p. 2). Clegg also points to the Church of England Book of Homilies that addresses "whoredome and adultery" (Cramner 1547, sig K3) and explains that it praises the "godlie statutes" of Islam that punish adultery by death (Cramner 1547, sig L4). Clegg states that "Islamic law ... would have been part of Othello the Moor's experience" (Clegg 2019, p. 3). 
When Emilia knocks at the chamber door, Othello ponders his response as his realization of his divided nature dawns:

If she comes in, she'll sure speak to my wife.

My wife! My wife! What wife? I have no wife.

Oh, insupportable! Oh, heavy hour!

Methinks it should now a huge eclipse

Of sun and moon, and that th' affrighted globe

Should yawn at alteration. (5.2.96-101)

Othello blames his actions on the moon, the Islamic symbol:

It is the very error of the moon;

She comes more nearer earth than she was wont,

And makes men mad. (V.2.109-11)

The "huge eclipse" of sun (Son) and moon depicts the split in Othello's identity as he struggles between Christianity-the sun, and Islam-the moon. The Bible contains numerous sun or light images to represent God or Jesus, as in "the lord God is a sun" (Psalm 84:11, KJV) and "the sun of righteousness" (Malachi 4:2, KJV). Thus, the two religious systems symbolically war within Othello.

Emilia recognizes the gaping spiritual void between the spouses and her personal espousal of Christianity, with Desdemona "the more angel" and Othello "the blacker devil" (5.2.130, 131). Growing awareness of the true nature of his actions begins to horrify Othello as he recognizes the ramifications of his descent into spiritual chaos. Tension increases when Gratiano, Iago, and Montano arrive while Emilia informs Othello of his wife's innocence. Furious, Iago stabs Emilia and escapes temporarily while Othello soberly confronts his guilt as a citizen of a Christian society that will neither understand nor approve his Sharia code of honor. He surrenders his judicial role, stepping back into his former Christian identity or possibly eschewing both faiths: "But why should honor outlive honesty? / Let it go all" (5.2.245-46). To Lodovico, Othello terms himself an "honorable murderer" (5.2.294) and offers the chilling defense: "For naught I did in hate, but all in honor" (5.2.295). However, earlier, as if recognizing his huge mistake in logic, he retreats from reality to speak of himself in third person: "Man but a rush against Othello's breast, / And he retires. Where should Othello go?" (5.2.270-71). Accepting guilt from the Christian perspective of the murder, Othello pronounces self-condemnation to everlasting hell as the spiritual consequence of his gravely mistaken identity: "Blow me about in winds! roast me in Sulphur! / Wash me in steep-down gulfs of liquid fire!" (5.2.280-81). Perhaps recognizing that he has failed in both his Christian faith and Sharia ideals, he abandons his identity altogether, saying, "That's he that was Othello" (5.2.284).

However, in suicide, Othello reclaims his role of judge and executioner-this time as a Christian-and takes his life in a way that seeks to obfuscate the damnable sin of self-slaughter by presenting the act as the lawful Christian execution of a criminal Muslim foe. Immediately before he stabs himself, he seeks to distinguish his Christian and Muslim identities by eliding his suicide into an earlier heroic military exploit in which he defended "a Venetian" and "the state" from "a malignant and turban'd Turk" as follows: "I took by th' throat the circumcised dog / and smote him-thus" (5.2.354, 356-67). Collapsing on the bed with the bodies of Desdemona and Emilia, Othello becomes a victim of the chaos that has ensued from his shifting religious identities, his own duplicity, and his misguided role of avenger.

Lodovico's directive of "Let it be hid" directs the bed curtains to be drawn to veil the deceased, permanently sealing Othello's final identity as a man deluded and destroyed by confused beliefs. Dennis Britton believes the tragedy "dramatizes the elusive interplay between Othello's Moorishness and his infidelity to Christianity" (Britton 2014, p. 112). He argues that "it is the very ambiguity of 
Othello's identification that ought to command our attention" (Britton 2014, p. 126). Othello's final words illustrate his dual nature divided between competing beliefs as he dictates his message for Venice in a final summary of his character. ${ }^{9}$

In self-murder that simultaneously poses as the expected military execution of a Muslim foe, Othello's allegiance to Christian society replaces his earlier Muslim obligation to protect his honor. He had first turned Christian, then turned back to Islam, and now finally turns again to Christianity, a bizarre parallel to his earlier accusation of Desdemona's repeated turning in his diatribe to Lodovico. Patently accepting Iago's false witness of Desdemona's adultery, Othello imposed Sharia to kill his wife. As Othello now shrinks from his crime into his former identity as the Christian defender of Venice, Christian law must be meted by and to the murderer. Ironically, Othello's final act of shifting religious identity, in light of the Catholic Christianity he now claims to again champion, serves to indeed lead him to the perdition he had previously warned of, for his mortal sin of suicide, in light of contemporary Catholic theology, places him among the damned.

Also complicating Othello's final act is that, in killing himself even as he announces the death of the Muslim "circumcised dog" whom he slew, he implicitly identifies himself as Muslim, demonstrating that the confusion of Othello's shifting religious identities is never resolved. This lack of resolution is suggested by Julia Reinhard Lupton:

In his suicide speech, Othello's drawn sword at once points outward to circumcision as the trait identifying the object of his scorn, and reflexively returns it onto Othello's own body as the very means of death, a final stroke that cuts off his life by turning the Turk into and onto himself" (Lupton 1997, p. 83).

In his death, Othello confirms his Muslim identity even as he extinguishes it.

In the end, Othello is a man conflicted in his religious identity, struggling to sort friends from enemies and truth from lies. From orphan to slave, from general to murderer, Othello's character plays a range of roles to fascinate theatre audiences and readers. His character is imbued with multiple layers of meaning explored by critics, viewers, readers, and Othello himself, as noted by Emily Bartels, who offers an impression of Othello as an incarnation of Venice: “ . . in the end, we cannot really tell where Venice's story stops and the Moor's story begins, so seamless and boundless is the cross-cultural exchange that Shakespeare stages" (Bartels 2008, p. 190). Ultimately, Othello's identity is rich and mysterious, replete with its own magic paralleling that of the handkerchief. Lacking friends, family, or faith, Othello turns inward and finds his hidden identity to address a crumbling marriage and damaged reputation. As his character desperately "turns," Othello tries to redeem his once-good name for posterity and seeks to confirm a final religious identity, as Daniel Boyarin points out:

The reason that Othello wants his Aleppan exploit spoken of is not to extenuate his circumstances but only to make us understand that he dies a Christian, a proper Venetian-he is not a circumcised pagan murderer but a Christian who killed his wife for honor. (Boyarin 2011, p. 258)

However, as we have already discussed, Othello's stated intention to die as a Christian also implicitly confirms that he dies as a Muslim. In the turmoil of his final days, Othello shifts from Christian protector

9 More completely, Othello's final words are as follows:

Set down this;

And say besides, that in Aleppo once,

Where a malignant and a turban'd Turk

Beat a Venetian and traduc'd the state,

I took by th' throat the circumcised dog,

And smote him-thus. [He stabs himself] (5.2.351-56) 
of Venice and his marriage to Muslim defender of society and his honor to one who desperately and dubiously seeks to reaffirm his status as a respected Venetian Christian. Thus, conflicting roles and religions destroy the Moor whose regret and self-punishment balance Desdemona's condemnation and murder by paying for her life with his.

Funding: This research received no external funding

Conflicts of Interest: The author declares no conflict of interest.

\section{References}

Alharbi, Rakan. 2015. Guardianship Law in Saudi Arabia and Its Effects on Women's Rights. Working Paper. Berlin, Germany: ResearchGate. Available online: https://www.researchgate.net/publication/318458165_ Guardianship_Law_in_Saudi_Arabia_and_Its_Effects_on_Women|T1|textquoterights_Rights (accessed on 2 February 2019).

Almadani, Wjoud. 2014. Marriage and Adultery in Renaissance Drama. International Journal of Languages and Literatures 2: 57-72.

Bartels, Emily C. 2008. Speaking of the Moor: From Alcazar to Othello. Philadelphia: U of Penn Press.

Bate, Jonathan. 2001. Othello and the Other: Turning Turk: The Subtleties of Shakespeare's Treatment of Islam. Times Literary Supplement. September 19. Available online: http://www2.idehist.uu.se/distans/ilmh/Ren/shothello-bate.htm (accessed on 5 October 2018).

Berek, Peter. 1998. The Jew as Renaissance Man. Renaissance Quarterly 51: 128-62. [CrossRef]

Borde, Andrew. 1547. The First Book of the Introduction of Knowledge (1547). The Norton Anthology of English Literature: Norton Topics Online. Available online: https://www.wwnorton.com/college/english/ nael/16century/topic_2/bordmoor.htm (accessed on 18 February 2019).

Boyarin, Daniel. 2011. Othello's Penis: Or, Islam in the Closet. In Shakesqueer: A Queer Companion to the Complete Works of Shakespeare. Edited by Madhavi Menon. Durham: Duke UP, pp. 254-62.

Brians, Paul. 1526. Leo Africanus: Description of Timbuktu from The Description of Africa. Available online: https://brians.wsu.edu/2016/11/04/leo-africanus-description-of-timbuktu-from-the-description-ofafrica-1526/ (accessed on 7 July 2019).

Britton, Dennis Austin. 2014. Becoming Christian: Race. Reformation, and Early Modern English Romance. New York: Fordham UP.

Brotton, Jerry. 2005. St. George Between East and West. London: Palgrave Macmillan, pp. 50-65.

Brotton, Jerry. 2016. The Sultan and the Queen. New York: Viking Press.

Clegg, Cyndia Susan. 2006. English Renaissance Books on Islam and Shakespeare's Othello. Pacific Coast Philology 41: $1-12$.

Clegg, Cyndia Susan. 2019. The Undiscovered Countries: Shakespeare and the Afterlife. Religions 10: 174. [CrossRef]

Cox, John. 2018. Shakespeare and Religion. Religions 9: 343. [CrossRef]

Degenhardt, Jane Hwang. 2010. Islamic Conversion and Christian Resistance on the Early Modern Stage. Edinburgh: Edinburgh UP.

Dimmock, Matthew. 2015. Shakespeare's non-Christian religions. In Shakespeare and Early Modern Religion. Edited by David Lowenstein and Michael Witmore. Cambridge: Cambridge University Press, pp. 280-99.

Fatoohi, Louay. 2015. The Meaning of 'Hadith'. Qur'anic Studies: Writings about the Qur'an, Islam, and Religion. Available online: http://www.quranicstudies.com/prophet-muhammad/the-meaning-of-hadith/ (accessed on 7 May 2019).

Graf, Tobias P. 2018. Best of Enemies: Europeans in the Ottoman Elite. History Today. January 2. Available online: https://www.historytoday.com/miscellanies/best-enemies-europeans-ottoman-elite (accessed on 23 July 2019).

Habib, Imtiaz. 2014. The Black Alien in Othello: Beyond the European Immigrant. In Shakespeare and Immigration. Edited by Ruben Espinosa and David Ruiter. London: Taylor \& Francis Group, pp. 128-49.

Hamlin, Hannibal. 2013. The Bible in Shakespeare. Oxford: Oxford University Press. 
Johanyak, Debra. 2009. 'Turning Turk,' Modern English Orientalism, and Othello. In The English Renaissance, Orientalism, and the Idea of Asia. Edited by Debra Johanyak and Walter S. H. Lim. Basingstoke: Palgrave Macmillan, pp. 77-95.

Jones, Lindsey. 2004. History of Sharia. In Encyclopedia of Religion, 2nd ed. Beijing: Macmillan, Available online: https://www.islamawareness.net/Shariah/sh_article005.html (accessed on 17 September 2018).

Kabbani, Shaykh Muhammad Hisham. 2007. The Case of Adultery. The Islamic Supreme Council of America. Available online: http://www.islamicsupremecouncil.org/understanding-islam/legal-rulings/ 52-understanding-islamic-law.html (accessed on 22 September 2018).

Knolles, Richard. 1603. The General Historie of the Turks from the First Beginning of that Nation to the Rising of the Ottoman Familie: With All of the Notable Expeditions of the Christian Princes against Them. Together with the Lives and Conquests of the Ottoman Kings and Emperours Faithfullie Collected out of the Histories Both Antient and Modern, and Digested into One Continual Historie Until This Present Yeare 1603. London: Adam Islip.

Leo, Africanus. 1600. A Geographical Historie of Africa. Translated by John Pory. London: Eliot's Court Press, Available online: https://quod.lib.umich.edu/e/eebo/A05331.0001.001/1:26.2?rgn=div2;view=toc (accessed on 14 Jan 2019).

Lupton, Julia Reinhard. 1997. Othello Circumcised: Shakespeare and the Pauline Discourse of Nations. Representations, 73-89. [CrossRef]

MacLean, Gerald. 2005. Re-Orienting the Renaissance: Cultural Exchanges with the East. Foreword by William Dalrymple. Basingstoke: Palgrave.

Marx, Steven. 2000. Shakespeare and the Bible. Oxford: Oxford University Press.

Scott, Emmet. 2016. The Islamic Trade in European Slaves. New English Review. December. Available online: https://www.newenglishreview.org/Emmet_Scott/The_Islamic_Trade_in_European_Slaves/ (accessed on 15 January 2019).

Shaheen, Naseeb. 1999. Biblical References in Shakespeare's Plays. Newark: University of Delaware Press.

Vitkus, Daniel. 2000. Three Turk Plays from Early Modern England. New York: Columbia UP.

Wood, Michael. 2012. Britain's First Black Community in Elizabethan London. BBC News. Available online: https://www.bbc.com/news/magazine-18903391 (accessed on 15 January 2019).

Yusuff, Mohamad K. 1999. Honor Killings in the Name of Religion. Louisville: Islamic Research Foundation International, Inc., Available online: http://irfi.org/articles/women_in_islam/honor_killings_in_the_name_ of_re.htm (accessed on 18 August 2018).

(C) 2019 by the author. Licensee MDPI, Basel, Switzerland. This article is an open access article distributed under the terms and conditions of the Creative Commons Attribution (CC BY) license (http://creativecommons.org/licenses/by/4.0/). 